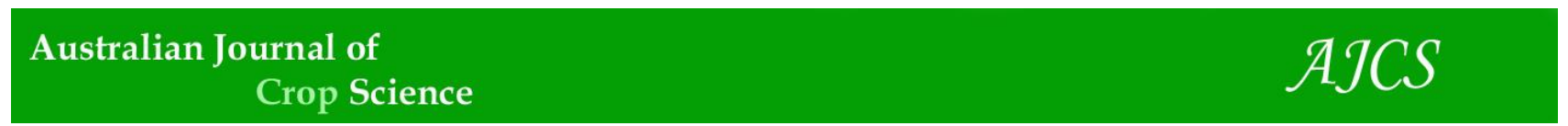

AJCS 14(10):1675-1681 (2020)

ISSN:1835-2707

doi: 10.21475/ajcs.20.14.10.p2723

\title{
Intercropping of beet with salad rocket (Eruca sativa) using hairy woodrose (Merremia aegyptia) plus manure goat in loam argisol yellow red latosol
}

\author{
Lunara de Sousa Alves ${ }^{1}$, Paulo César Ferreira Linhares ${ }^{2 *}$, Roberto Pequeno de Sousa ${ }^{2}$, Janilson Pinheiro de Assis ${ }^{2}$, \\ Thiago Jardelino Dias ${ }^{1}$, Joaquim Odilon Pereira ${ }^{3}$, Eudes de Almeida Cardoso ${ }^{2}$, Robson Pequeno de Sousa ${ }^{4}$, Mateus de \\ Freitas Almeida dos Santos ${ }^{2}$, Walter Martins Rodrigues ${ }^{3}$, Geovanna Alícia Dantas Gomes ${ }^{2}$, Anderson Bruno Anacleto \\ de Andrade $^{2}$ and Maria Fernanda de Oliveira Soares ${ }^{2}$ \\ ${ }^{1}$ Federal University of Paraiba, Campus Areia, Areia-PB, 58397-000, Brazil \\ ${ }^{2}$ Federal Rural Semi-Arid University, Department of Agronomic and Forestry Sciences, Jitirana Research Group, \\ Mossoró-RN, 59625-900, Brazil \\ ${ }^{3}$ Departamento de Engenharias e Ciências Ambientais, Universidade Federal Rural do Semi Árido, Mossoró, Brazil, \\ Mossoró-RN, 59625-900, Brazil \\ ${ }^{4}$ Computing Department, State university of Paraíba, Campina Grande-PB, 58429-500, Brazil
}

*Corresponding author: paulolinhares@ufersa.edu.br

\begin{abstract}
The crop intercropping is a viable option for family farmers who grow in small spaces and need to take advantage of all the available area. The objective of this study was to evaluate the agronomic viability of the intercropping of beet with salad rocket (arugula) under different amounts of Merremia aegyptia plus goat manure. The experiment was conducted at Rafael Fernandes Experimental Farm, in the Alagoinha district, rural area of Mossoró-RN, from August to December 2016. The experimental design was a randomized complete block with treatments arranged in a $2 \times 4$ factorial scheme, with three repetitions. The first factor was the single beet and second intercropped cultivation of beet and arugula. The second factor was the amount of Merremia aegyptia plus goat manure $\left(0.0,1.5,3.0\right.$ and $\left.4.5 \mathrm{~kg} \mathrm{~m}^{-2}\right)$. For the sugar beet crop the following characteristics were evaluated: plant height, fresh leaf mass, commercial root yield and root dry mass. For arugula culture the following characteristics were evaluated: plant height, number of leaves per plant, yield, number of sauces and dry mass. The best agronomic performance of the beet and rocket intercropping was obtained in the amount of $4.5 \mathrm{~kg} \mathrm{~m}^{-2}$ of $M$. aegyptia beds and goat manure. The consortium presented an area ratio equivalent to over 1.0, with an average value of 1.81 in the amount of $4.5 \mathrm{~kg} \mathrm{~m}^{-2}$ of $M$. aegyptia flowerbed plus goat manure. The consortium contributed to better use of available resources without compromising the commercial quality of the vegetables.
\end{abstract}

Keywords: Organic fertilization. Vegetables. Agronomic performance.

Abbreviations: UFERSA_Federal Rural Semi-Arid University; Ca_calcium; Mg_magnesium; P_phosphor and K_potassium.

Introduction

The exploitation of vegetables predisposes the soil to considerable losses of nutrients and organic matter, because the plants are quite demanding in relation to nutrition. Grangeiro et al. (2007) states that vegetables are grueling crops in terms of soil nutrients because they require high amounts of nutrients in a short period of time. In addition, the whole plant is harvested, leaving few cultural remains on the surface from soil.

Among the practices of sustainable production, intercropping vegetable has been used in agroecological systems, bringing benefits to the soil-plant system. According to Souza and Resende (2006), this technique allows greater productivity per area, due to the combination of species that will explore the physical space, nutrients, water and sunlight, besides favoring the control of pests, diseases and plants spontaneous.

For Gliessmam (2005), when two or more crops are planted within the same plot, the interactions that occur between them can have beneficial effects to all species, as well as considerably reduce the external inputs to the system. According to Altieri (2012), the systems of cultivation in a consortium, contributes to the reduction of losses due to pests due to the high variety of biological mechanisms.

This system of cultivation becomes efficient in terms of the acquisition and use of available resources in the farms, consisting in the mixture of organic fertilizers to be used in the organic production of vegetables. In this context, Merremia aegyptia is a promising species, due to its nutritional quality and green and dry biomass production, corresponding to 36000 and $4000 \mathrm{~kg} \mathrm{ha}^{-1}$ respectively, and nitrogen content of $26.2 \mathrm{~g} \mathrm{~kg}^{-1}$ (Linhares et al., 2008), with a $\mathrm{C} / \mathrm{N}$ ratio of $18 / 1$, which makes the species feasible for use as an organic fertilizer.

Organic fertilizers are mainly used for the supply of organic matter, and the use of these residues contributes to the formation of soil structure, promoting the increase of 
porosity and aeration, avoiding surface runoff losses (Silva, 2012).

An alternative source available on farms is goat manure, which is widely used by family farmers who produce in the organic production system.

Most of the technologies developed for family agriculture are aimed at increasing the productivity of the land, eliminating the idleness of the area or taking advantage of space (Fukushi, 2012).

In this sense, some important aspect to be considered in organic production of vegetables in a consortium system such as use of resources available on the farm, ensuring a higher profitability for the producer in a smaller physical space. This will ensuring a faster return on the investments applied. Almeida et al. (2015) studied the agronomic efficiency of lettuce intercropped with arugula fertilized with silk flower.

Therefore, the objective of this study was to evaluate the Intercropping of beet with arugula under amounts of $M$. aegyptia plus manure goat in loam argisol yellow red latosol.

\section{Results and Discussion}

\section{Beet intercropping with arugula}

We did not observe significant interaction as a function of the cultivation system (single and intercropping) due to the amount of $M$. aegyptia plus goat manure in any characteristic of the beet crop (Table 1).

The different amounts of goat manure and M. aegyptia, probably contributed to the improvement of the physical and chemical conditions of the soil promoting greater availability of nutrients to the beet plants at the time of greatest nutritional requirement of the plant.

\section{Plant height}

For the plant height, there was a mean increase of $9.2 \mathrm{~cm}$ plant $^{-1}$ between the highest amount $\left(4.5 \mathrm{~kg} \mathrm{~m}^{-2}\right)$ and the lowest amount $\left(0 \mathrm{~kg} \mathrm{~m}^{-2}\right)$, with an average height of $41.9 \mathrm{~cm}$ plant ${ }^{-1}$ in the amount of $4.5 \mathrm{~kg} \mathrm{~m}^{-2}$ of $M$. aegyptia plus goat manure (Figure 1). In the cultivation system (single and intercropped), the heights were statistically similar, with mean values of 37.1 and $37.0 \mathrm{~cm} \mathrm{plant}^{-1}$, respectively (Table 2).

Silva (2013) studied cultivation of lettuce intercropping with beet under different amounts of jitirana incorporated into the soil and spatial arrangements. They reported a height of $26 \mathrm{~cm}$ plant $^{-1}$ after application of $32 \mathrm{t} \mathrm{ha}^{-1}$ of jitirana incorporated into the soil. Similarly, Ramalho (2015) studied the intercropping of coriander with beet, fertilized with amounts of jitirana, combined with cattle manure in agroeconomic performance. They found a height of $25.2 \mathrm{~cm}$ beet plant $^{-1}$ after using $3.0 \mathrm{~kg} \mathrm{~m}^{-2}$ jitirana. This inferiority is possibly due to the amount of $4.5 \mathrm{~kg} \mathrm{~m}^{-2}$ of the M. aegyptia and goat manure mixture used in this research.

\section{Fresh leaf mass and commercial root productivity}

For fresh leaf mass, there was an increase in the amount of M. aegyptia plus goat manure, with an average value of 4.4 $\mathrm{kg} \mathrm{m}^{-2}$ with the application of $4.5 \mathrm{~kg} \mathrm{~m}^{-2}$ (Figure 2). In relation to the cultivation system (single and intercropping), there was superiority of the single system, with average values of 3.5 and $2.9 \mathrm{~kg} \mathrm{~m}^{-2}$, respectively (Table 2).

There was an increase of $3.76 \mathrm{~kg} \mathrm{~m}^{-2}$ of commercial root productivity between the highest amount $\left(4.5 \mathrm{~kg} \mathrm{~m}^{-2}\right)$ and the lowest amount $\left(0 \mathrm{~kg} \mathrm{~m}^{-2}\right)$, with an average value of 5.7 $\mathrm{kg} \mathrm{m}^{-2}$ of root productivity in the amount of $4.5 \mathrm{~kg} \mathrm{~m}^{-2}$ of $M$. aegyptia plus goat manure (Figure 3 ). Among the cultivation system (single and intercropping) there was superiority of the single crop with average values of 3.9 and $3.7 \mathrm{~kg} \mathrm{~m}^{-2}$, respectively (Table 2 ).

Fresh leaf mass is strongly influenced by nitrogen fertilization, which is possible due to nitrogen concentration in the organic fertilizer of $M$. aegyptia $(25.0 \mathrm{~g} \mathrm{~kg})$ and goat manure $\left(17.6 \mathrm{~g} \mathrm{~kg}^{-1}\right)$. According to Novaes (2007), nitrogen is responsible for vegetative development. Oliveira (2014) found fresh mass of the area of $15.05 \mathrm{t} \mathrm{ha}^{-1}$, equivalent to $1.5 \mathrm{~kg} \mathrm{~m}^{-2}$ in the amount of $55 \mathrm{t} \mathrm{ha}^{-1}$ of silk flower incorporated into the soil, being inferior to this research. These results are highlighted by Filgueira (2012), when he stated that the efficiency of the organic fertilizer is related to the greater availability of nutrients and activities of the microorganisms in the soil conditions, contributing to the development of the plant. Oliveira (2014), evaluated the agroeconomic performance of the intercropped beetroot cultivar as a function of the quantities of silk flower and found commercial productivity of $16.95 \mathrm{t} \mathrm{ha}^{-1}$ equivalent to $1.7 \mathrm{~kg} \mathrm{~m}^{-2}$ in the quantity of $51.1 \mathrm{t} \mathrm{ha}^{-1}$. Bezerra Neto et al. (2013) evaluated quantities of silk flower in beet crop with bean cowpea and found productivity of $16.35 \mathrm{t} \mathrm{ha}^{-1}$, equivalent to $1.6 \mathrm{~kg} \mathrm{~m}^{-2}$ in the amount of $46.8 \mathrm{t} \mathrm{ha}^{-1}$, being inferior to our study.

\section{Dry root mass}

In the dry root mass, there was an increase as a function of $M$. aegyptia and goat manure, with an average value of $440.2 \mathrm{~g} \mathrm{~m}^{-2}$, after application of $4.5 \mathrm{~kg} \mathrm{~m}^{-2}$ of M. aegyptia plus goat manure (Figure 4). Among the cultivation system (single and intercropping), there was superiority of the single crop, with mean values of 0.39 and $0.37 \mathrm{~kg} \mathrm{~m}^{-2}$, respectively (Table 2). According to Teiz and Zeig (2017), dry mass is one of the characteristics that best expresses plant growth. In the case of beet, the different amounts of $M$. aegyptia plus goat manure contributed to an expressive growth of the culture.

According to Teiz and Zeiger (2017), dry mass is one of the characteristics that best expresses plant growth. In the case of beet, the different amounts of jitirana combined with cattle manure possibly contributed to the root development.

\section{Arugula consortium with beets}

There was no statistical difference in the interaction between the quantities of $M$. aegyptia plus goat manure and in cultivation system (single crop and intercropping) for the characteristics of the arugula (Table 3).

We observed that the treatment with the largest amount of jitirana plus goat manure mixture provided the greatest increase in arugula culture characteristics. This is probably due to the higher amount of nitrogen available in organic fertilizer and the synchronization between nutrient availability by the organic fertilizer and the moment of demand of the crop being of paramount importance for productivity.

\section{Plant stature and number of leaves}

For the plant height, there was an average increase of $25 \mathrm{~cm}$ plant $^{-1}$ between 4.5 and $0 \mathrm{~kg} \mathrm{~m}^{-2}$, with an average height of 
$40.5 \mathrm{~cm}$ plant $^{-1}$ in the amount of $4.5 \mathrm{~kg} \mathrm{~m}^{-2}$ of M. aegyptia plus goat manure (Figure 5 ). In the cultivation system (single and intercropping) the heights were statistically similar, with average values of 37.1 and $37.0 \mathrm{~cm}$ plant $^{-1}$, respectively (Table 4).

Oliveira et al. (2010) found superior results to research in single arugula cultivation, with an average height of $23.9 \mathrm{~cm}$, in an experiment evaluating organic fertilization. Oliveira et al. (2015), evaluated the agronomic yield of arugula fertilized with different amounts of Calotropis procera. They found an average arugula height of $22.75 \mathrm{~cm}$ plant ${ }^{-1}$ with the addition of $70 \mathrm{t} \mathrm{ha}^{-1}$ Calotropis procera. Andrade Filho (2012), observed similar results, with the addition of increasing quantities of silk flower, obtaining a value of $14.0 \mathrm{~cm}$ in the height of arugula plants in the amount $13.09 \mathrm{t} \mathrm{ha}^{-1}$. For the number of leaves, there was an increase of 9.6 leaves plant ${ }^{-}$ ${ }^{1}$, in the amount of $4.5 \mathrm{~kg} \mathrm{~m}^{-2}$ of $M$. aegyptia plus goat manure (Figure 6). In the cultivation system (single and intercropping), there was superiority of single cultivation, with average values of 9.16 and 8.46 leaves plant ${ }^{-1}$, respectively (Table 4 ).

The number of leaves is an important characteristic, considering that the harvested plants need to have a marketing standard with an average number of six leaves plant $^{-1}$, in this sense, obtaining higher values determines the importance of organic fertilization.

\section{Yield and units of sauces}

The amount of $4.5 \mathrm{~kg} \mathrm{~m}^{-2}$ of $M$. aegyptia plus goat manure was what promoted the highest fresh mass productivity and number of sauces, with average values of $4.42 \mathrm{~kg} \mathrm{~m}^{-2}$ and 147.0 units $\mathrm{m}^{-2}$, respectively (Figures 7 and 8). Regarding the cultivation system (single and intercropping), there was superiority of single cultivation, with average values of 1021.6 and $877.3 \mathrm{~g} \mathrm{~m}^{-2}$ for yield, equivalent to 33.78 and 29.23 sauces $\mathrm{m}^{-2}$ (Table 5 ).

Oliveira et al. (2015), evaluating the agronomic yield of arugula fertilized with different amounts of Calotropis procera found value of 15.0 leaves plant ${ }^{-1}$ with the addition of $70 \mathrm{t} \mathrm{ha}{ }^{-1}$. Almeida et al. (2015) studying the agronomic efficiency of the lettuce rocket fertilized intercrop with $35 \mathrm{t}$ ha $^{-1}$ of silk flower, found 6.0 leaves plant ${ }^{-1}$, lower value than the study. Already, Oliveira et al. (2015), evaluating the agronomic yield of arugula fertilized with different amounts of Calotropis procera found number 15.0 leaves plant ${ }^{-1}$ with the addition of $70 \mathrm{t} \mathrm{ha}^{-1}$.

The number of sauces is the most important characteristic in commercial terms, considering that the commercialization of this crop in supermarket gondolas occurs through sauces. Silva (2012) observed a maximum yield of green mass (7.9 $\mathrm{t}$ $\mathrm{ha}^{-1}$, equivalent to $790 \mathrm{~g} \mathrm{~m}^{-2}$ ), in the combination of $45 \mathrm{tha}^{-1}$ of silk flower over 20 days before sowing the arugula.

Oliveira et al. (2015) evaluating the agronomic yield of arugula fertilized with $70 \mathrm{ha}^{-1}$ of Calotropis procera found green mass production of $1886 \mathrm{~g} \mathrm{~m}^{-2}$, equivalent to $1.8 \mathrm{~kg} \mathrm{~m}^{-}$ ${ }^{2}$, higher than the study developed. Probably the quantity of $70 \mathrm{t} \mathrm{ha}^{-1}$ was what contributes to a higher productivity than the developed study. Linhares et al. (2017) evaluating polycultures of coriander carrot and arugula in stripintercropping system, found productivity $1.48 \mathrm{t} \mathrm{ha}^{-1}$, equivalent to $0.148 \mathrm{~kg} \mathrm{~m}^{-2}$, which is below the research developed.

\section{Dry mass}

In root dry mass, there was an increase with the application of amounts of jitirana plus goat manure, with an average value of $162.0 \mathrm{~g} \mathrm{~m}^{-2}$, in the amount of $4.5 \mathrm{~kg} \mathrm{~m}^{-2}$ of $M$. aegyptia plus goat manure (Figure 9 ). Among the cultivation system (single and intercropping) there was superiority of single cultivation with average values of 390.0 and $370.0 \mathrm{~g}$ $\mathrm{m}^{-2}$, respectively (Table 5 ).

Dry matter mass is a very important characteristic, as it more directly reflects plant growth, being the most appropriate for growth analysis (Teiz and Zeiger 2017), reflecting the influence of the treatments imposed on the crop.

Oliveira et al. (2010), studied the lettuce and arugula intercropping with incorporation of organic fertilizers and found a dry mass value of arugula equivalent to $0.24 \mathrm{~kg} 2.0$ $\mathrm{m}^{-2}$, being within the range found in this study. Rezende et al. (2006) found a higher value of arugula dry mass of 55.19 $\mathrm{g} \mathrm{m}^{-1}$ equivalent to $0.11 \mathrm{~kg} 2.0 \mathrm{~m}^{-2}$, when studying the intercrop with bell pepper and radish.

\section{Equivalent area ratio}

The intercropping showed potential use of productive space, represented by the ratio of equivalent area (EAR), with value of 1.83 , in the amount of $4.5 \mathrm{~kg} \mathrm{~m}^{-2}$ of flowerbed (Fig 10). This means that the intercropping was effective, requiring an increase of $83 \%$ of cultivated area to obtain, through single cultivation, productivity equivalent to that achieved with the arugula beet intercropping.

In the intercropping of vegetables, there has been compensation between the crops by EAR. Costa (2006), evaluated the lettuce and arugula intercropping, according to the cultivation season and the arugula sowing time in relation to the transplantation of three lettuce cultivars. They found that the efficiency indexes of the use of the consortium area varied from 1.08 to 2.02 .

The production of vegetables grown in consortium, compared to single cultivation, is advantageous for the production of different cultivated species, demonstrating a potential of intercropping of these vegetables, especially for small areas, where the exploitation of productive exploitation tends to be higher indicating that the systems intercropping companies made better use of the environmental resources available compared to single cultivation.

\section{Materials and methods}

\section{Plant materials}

The experiment was conducted in the research area of the Rafael Fernandes Experimental Farm of the Federal Rural Semi-Arid University (UFERSA), in the period from August to December 2016. The soil of the experimental area was classified as Eutrophic Red Yellow Argissolo, caatinga hyperxerophilic phase and flat relief (Embrapa, 2006). The area is located in the Alagoinha district, $20 \mathrm{~km}$ from the Mossoró, Northeastern Brazil. The farm comprises of 400 hectares (Rêgo et al., 2016).

According to Kottek et al. (2006) and the classification of Köppen, the local climate is BSwh', dry and very hot. The dry season is normally from June to January, and a rainy season from February to May. The average annual rainfall is 673.9 $\mathrm{mm}$ and the average relative humidity is $68.9 \%$. 
Before the installation of the field experiment, soil samples processing and analysis in the UFERSA Water, Soil and Plant were collected to a $0-20 \mathrm{~cm}$ layer and then sent for

Table 1. F-values for plant height (PH), fresh mass yield (FMY), root productivity (RP) and root dry mass (RDM) of beet in loam argisol yellow red latosol.

\begin{tabular}{llllll}
\hline Causes of variation & GL & PH & FMY & RP & RDM \\
\hline Amounts of fertilizer (a) & 3 & $9.6^{* *}$ & $54.3^{* *}$ & $15.9^{\text {n* }}$ & $12.1^{* *}$ \\
Cultivation system (c) & 1 & $0.002^{\text {ns }}$ & $10.3^{* *}$ & $0.28^{\text {ns }}$ & $2.08^{\text {ns }}$ \\
A x B & 3 & $0.52^{\text {ns }}$ & $1.2^{\text {ns }}$ & $0.21^{\text {ns }}$ & $0.89^{\text {ns }}$ \\
Treatments & 7 & --- & --- & --- & --- \\
Blocks & 2 & $0.15^{\text {ns }}$ & $1.9^{\text {ns }}$ & $6.21^{*}$ & $7.7^{* *}$ \\
Waste & 14 & --- & --- & -- & -- \\
CV $(\%)$ & --- & 14.4 & 14.3 & 23.7 & 25.07 \\
\hline
\end{tabular}

${ }^{* *}=\mathrm{P}<0.01$, statistical significance at $1 \%$ probability $^{*}=\mathrm{P}<0.05$, statistical significance at $5 \%$ probability and ${ }^{\mathrm{ns}}=$ not significant.

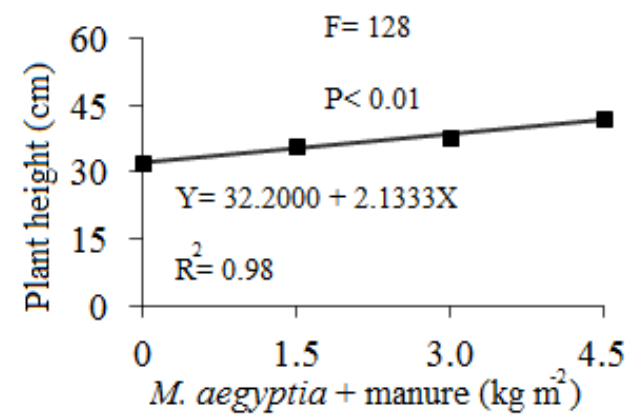

Fig 1. Height of beet plant under quantities of M. aegyptia mix plus goat manure.

Table 2. Plant height in $\mathrm{cm}^{-1}$ plant $^{-1}(\mathrm{PH})$, fresh leaf dough $\mathrm{kg} \mathrm{m}^{-2}$ (FLD), commercial root productivity $\mathrm{kg} \mathrm{m}^{-2}$ (CRP) and root dry mass, $\mathrm{kg} \mathrm{m}^{-2}$ (RD) of beet in loam argisol yellow red latosol.

\begin{tabular}{lllll}
\hline Cultivation system & PH & FLD & CRP & RD \\
\hline Single crop & $37.2 \mathrm{a}$ & $3.5 \mathrm{a}$ & $3904.1 \mathrm{a}$ & $343.0 \mathrm{a}$ \\
Intercropping & $37.0 \mathrm{a}$ & $2.9 \mathrm{a}$ & $3707.5 \mathrm{a}$ & $295.7 \mathrm{a}$ \\
CV $(\%)$ & 14.4 & 14.3 & 23.7 & 25.0 \\
\hline
\end{tabular}

*Means followed by the same letter in the column do not differ by Tukey test at the $5 \%$ probability level.

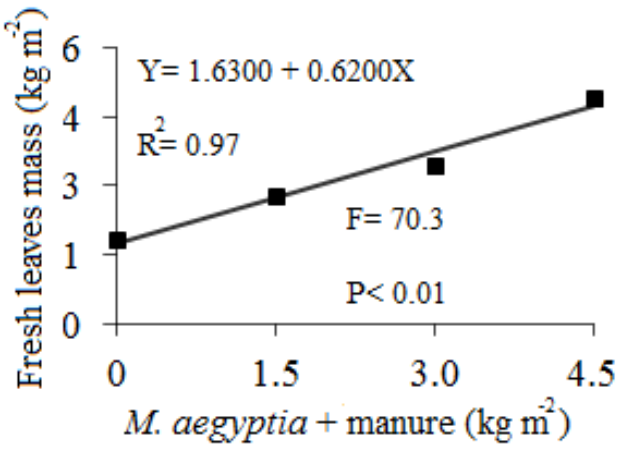

Fig 2. Fresh leaves mass under quantities of M. aegyptia mix plus goat manure.

Table 3. $F$ values for plant height (PH), number of leaves (NL), arugula productivity (AP), number of sauces (NS) and dry mass (DM) of arugula in loam argisol yellow red latosol

\begin{tabular}{|c|c|c|c|c|c|c|}
\hline Causes of variation & GL & AP & NF & $\mathrm{PD}$ & NM & MS \\
\hline Amounts of fertilizer (a) & 3 & $12.1^{* *}$ & $7.04^{* *}$ & $25.4^{* * 7}$ & $26.1^{* *}$ & $4.07^{*}$ \\
\hline Cultivation system (c) & 1 & $2.8^{\mathrm{ns}}$ & $4.6^{*}$ & $5.04^{*}$ & $4.4^{\mathrm{ns}}$ & $0.02^{\mathrm{ns}}$ \\
\hline$A \times B$ & 3 & $2.3^{\mathrm{ns}}$ & $2.5^{\mathrm{ns}}$ & $1.6^{\mathrm{ns}}$ & $1.7^{\mathrm{ns}}$ & $0.7^{\mathrm{ns}}$ \\
\hline Treatments & 7 & --- & --- & --- & --- & --- \\
\hline Blocks & 2 & $0.35^{\text {ns }}$ & $0.02^{\text {ns }}$ & $0.9^{\mathrm{ns}}$ & $0.8^{\mathrm{ns}}$ & $2.6^{\mathrm{ns}}$ \\
\hline Waste & 14 & --- & --- & --- & --- & --- \\
\hline CV (\%) & -- & 11.2 & 9.02 & 16.5 & 16.7 & 21.2 \\
\hline
\end{tabular}




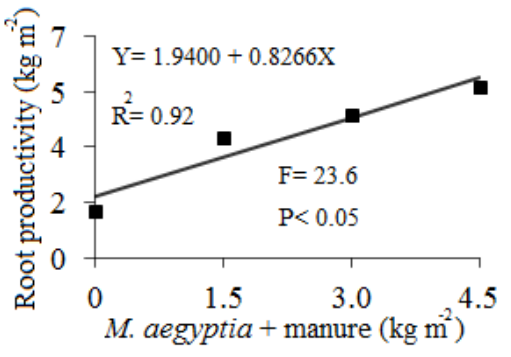

Fig 3. Root productivity under quantities of $M$. aegyptia mix plus goat manure

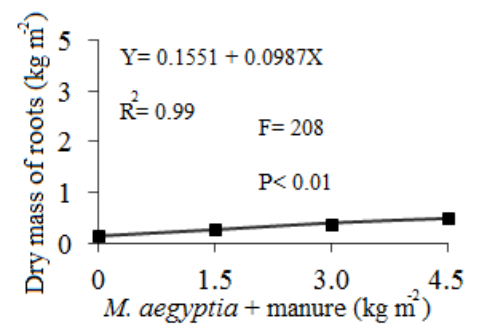

Fig 4. Dry mass of roots under quantities of M. aegyptia mix plus goat manure

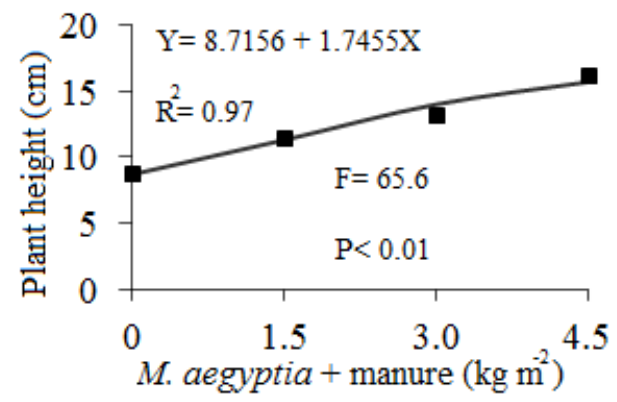

Fig 5. Height of arugula plant under quantities of $M$. aegyptia mix plus goat manure

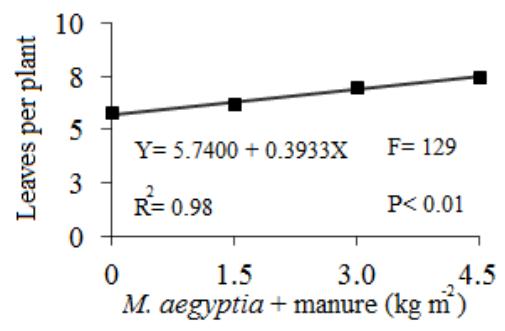

Fig 6. Leaves per plant of arugula under quantities of $M$. aegyptia mix plus goat manure

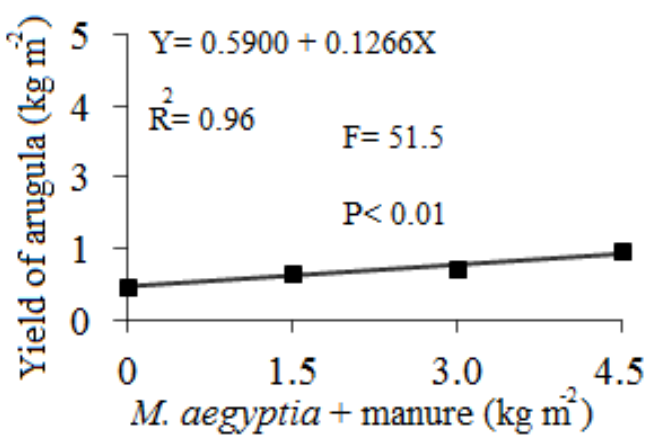

Fig 7. Yield of arugula under quantities of M. aegyptia mix plus goat manure

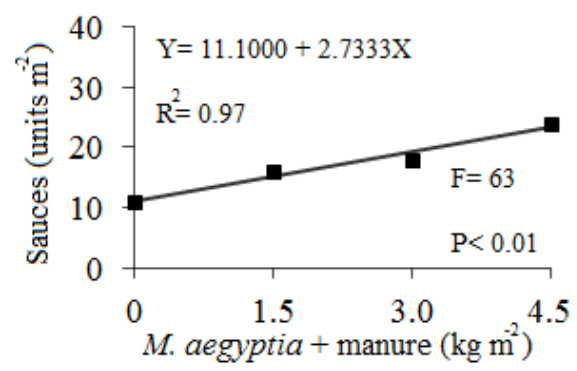

Fig 8. Number of arugula sauces under quantities of $M$. aegyptia mix plus goat manure

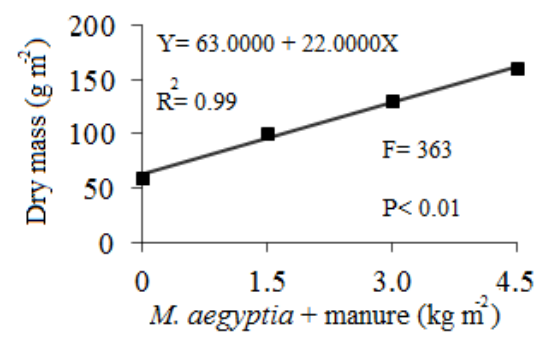

Fig 9. Dry mass of arugula sauces under quantities of $M$. aegyptia mix plus goat manure.

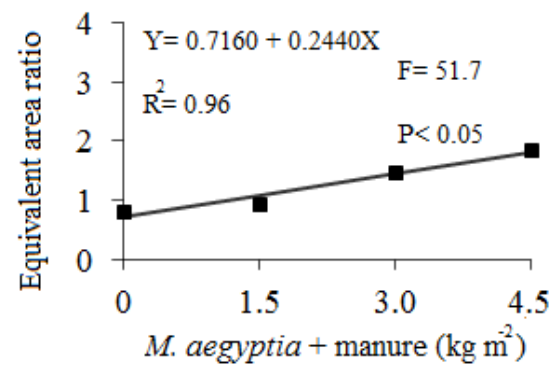

Fig 10. Equivalent area ratio of intercropping under quantities of $M$. aegyptia mix plus goat manure. 
Analysis Laboratory, providing the following results: $\mathrm{pH}$ (water 1:2,5) $=6.80 ; \quad$ exchangeable cations $\mathrm{Ca}=0.75$ $\mathrm{cmol}_{\mathrm{c}} / \mathrm{dm}^{3} ; \mathrm{Mg}=0.94 \mathrm{cmol}_{\mathrm{c}} / \mathrm{dm}^{3} ; \mathrm{K}=44.8 \mathrm{mg} / \mathrm{dm}^{3} ; \mathrm{Na}=8.0$ $\mathrm{mg} / \mathrm{dm}^{3} ; \mathrm{P}$ (Mehlich) $=5.3 \mathrm{mg} / \mathrm{dm}^{3} ;$ organic matter $=2.4 \mathrm{~g} / \mathrm{kg}$; Coarse sand $=630 \mathrm{~g} / \mathrm{kg}$; fine sand $=270 \mathrm{~g} / \mathrm{kg}$; silte $=20 \mathrm{~g} / \mathrm{kg}$; clay $=70 \mathrm{~g} / \mathrm{kg}$, soil density $=1.42 \mathrm{~g} / \mathrm{cm}^{3}$.

\section{Statistical delineation and treatments}

The experimental design of randomized complete blocks with the treatments arranged in $4 \times 2$ factorial scheme, with four replicates. The first factor was composed of the amounts of hairy woodrose plus goat manure $(0.0 ; 1.5 ; 3.0$ and $4.5 \mathrm{~kg} \mathrm{~m}^{-2}$ ) chosen according to the quantities of fertilizer used by family farmers. The second factor for the cropping system (single and intercropping).

They consisted of the following treatments: $\mathrm{T} 1$, Beet and rocket intercropping in the amount of $0 \mathrm{~kg} \mathrm{~m}^{-2} ; \mathrm{T} 2$, beet and rocket intercropping in the amount of $1.5 \mathrm{~kg} \mathrm{~m}^{-2} ; \mathrm{T} 3$ beet and rocket intercropping in the amount of $3.0 \mathrm{~kg} \mathrm{~m}^{-2} ; \mathrm{T} 4$, beet and rocket intercropping in the amount of $4.5 \mathrm{~kg} \mathrm{~m}^{-2}$; $\mathrm{T} 5$, monoculture of rocket of $0 \mathrm{~kg} \mathrm{~m}^{-2} ; \mathrm{T} 6$, monoculture of rocket of $1.5 \mathrm{~kg} \mathrm{~m}^{-2} ; \mathrm{T7}$, monoculture of rocket of $3.0 \mathrm{~kg} \mathrm{~m}^{-2}$; $\mathrm{T} 8$, monoculture of rocket of $4.5 \mathrm{~kg} \mathrm{~m}^{-2} ; \mathrm{T} 9$, monoculture of beet in the amount of $0 \mathrm{~kg} \mathrm{~m}^{-2} ; \mathrm{T} 10$, monoculture of beet in the amount of $1.5 \mathrm{~kg} \mathrm{~m}^{-2} ; \mathrm{T} 11$, monoculture of beet in the amount of $3.0 \mathrm{~kg} \mathrm{~m}^{-2}$ and T12, monoculture of beet in the amount of $4.5 \mathrm{~kg} \mathrm{~m}^{-2}$. The ratio of 1: 1 was used for the amounts of hairy woodrose plus goat manure. The fertilization of $M$. aegyptia plus goat manure was incorporated into the soil for a period of 30 days before planting of the crops, as recommended by Linhares et al. (2012).

\section{Agronomic practices}

The soil preparation was manually carried out by cleaning of the experimental area with the aid of a hoe, followed by harrowing and the construction of the beds, using mechanized rotary tool.

The hairy woodrose (Merremia aegyptia L.) was harvested in the herbaceous vegetation inside the Federal Rural SemiArid University (UFERSA) at the beginning of the flowering period, when the plant presents the maximum concentration of nutrients. The plants were crushed in a forage machine, obtaining segments between 2.0 and 3.0 $\mathrm{cm}$, dehydrated in the sun to be used as an organic fertilizer according to Linhares (2011). The plant samples were sent to the Laboratory of Soil Fertility and Plant Nutrition, UFERSA for chemical analysis and the results were as follows: $570 \mathrm{~g}$ $\mathrm{kg}^{-1} \mathrm{C} ; 25.0 \mathrm{~g} \mathrm{~kg}^{-1} \mathrm{~N} ; 12.5 \mathrm{~g} \mathrm{~kg}^{-1} \mathrm{P} ; 18.0 \mathrm{~g} \mathrm{~kg}^{-1} \mathrm{~K} ; 12.0 \mathrm{~g} \mathrm{~kg}^{-1} \mathrm{Ca}$; $16.0 \mathrm{~g} \mathrm{~kg}^{-1} \mathrm{Mg}$, with carbon/nitrogen ratio of 23:1.

The goat manure was used and the sourced came from the poultry sector of UFERSA, fed with Canarian grass (Echinocloa polystochya), which chemical concentration of: $\mathrm{pH}$ (water 1: 2.5) = 8.06; and the total contents of $17.6 \mathrm{~g} \mathrm{~kg}^{-1}$ of $\mathrm{N} ; 0.667 \mathrm{~g} \mathrm{~kg}^{-1}$ of $\mathrm{P} ; 5.827 \mathrm{~g} \mathrm{~kg}^{-1}$ of K+$; 1.849 \mathrm{~g} \mathrm{~kg}^{-1}$ of $\mathrm{Na}^{+}$; $0.197 \mathrm{~g} \mathrm{~kg}^{-1}$ of $\mathrm{Ca}^{2+}$ and $0.037 \mathrm{~g} \mathrm{~kg}^{-1}$ of $\mathrm{Mg}^{2+}$ ).

\section{Harvest and evaluation}

After harvesting, plants were transported to the PostHarvest of Vegetables Laboratory at the Department of
Agronomic and Forestry Sciences at UFERSA where they were analyzed.

The beet plants were harvested 85 day after planting, and the following traits were estimated: plant height (determined from a sample of twenty plants of the useful area, being measured through a ruler, from the ground level to the inflection of the highest leaf, being expressed in centimeter plant $^{-1}$ ), number of leaf per plant (determined in a sample of twenty plants, and expressed in terms of mean), commercial root (fresh weight of roots, free of cracks, bifurcations, nematodes, and mechanical damages, expressed in $\mathrm{kg} \mathrm{m}^{-2}$ ) and dry mass root (was obtained from a forced-air heating oven at $65 \stackrel{\circ}{\circ}$, until constant mass was attained and measured in $\mathrm{kg} \mathrm{m}^{-2}$ ).

For the arugula cultivar, harvested at 35 days after sowing, the following characteristics were evaluated: plant height (was measured from base to was apex in twenty plant sample batches, using a millimeter ruler and recorded in $\mathrm{cm} /$ plant), number of leaf per plant (was determined in twenty plant sample averages), green mass production (was obtained from a cut of the shoot system and weighted with an electronic scale at a precision of $1.0 \mathrm{~g}$ measured in $\mathrm{kg} / \mathrm{m}^{2}$ ), number of bunches (this was evaluated dividing the green mass by $30 \mathrm{~g}$, equivalent to the weight of a arugula bunch, according to information from organic producers in the region of Mossoró-RN, and measured in units $\mathrm{m}^{2}$ ), and dry mass (was obtained from a forced-air heating oven at 65 oC, until constant mass was attained and measured in $\mathrm{g} \mathrm{m}^{-2}$ ). The efficiency of the intercropping system was evaluated by the land equivalent ratio (LER) that is calculated using the formula: $\operatorname{LER}=($ Ybecar/Ybe $)+($ Yarbe/Yar) Where, Ybecar $=$ commercial beet root in intercropping with arugula; Ybe = commercial beet root in monocropping; Yarbe = green mass of arugula in intercropping with beet; Yar = green mass of arugula in monocropping.

The efficiency of each treatment was estimated using the efficiency index model described by Charnes et al. (1978). For the calculation of the LER, productivity values of beet and arugula were used based on an effective area of $1.0 \mathrm{~m}^{2}$ of land for monocropping and intercropping, corresponding to the area used by family farmers of vegetables in the Northeast of Brazil.

\section{Statistical analysis}

The statistical application used was ESTAT (Kronka and Banzato 1995). The response curve adjustment procedure for the quantitative factor (the mixture of hairy woodrose plus goat manure) was performed using the Table Curve 2D (Jandel Scientific, 1991) and, for the qualitative factor (single cropping, and intercropping, of beet and rocket) the F test, obtained in the analysis of variance, was used.

\section{Conclusions}

The best agronomic performance of the system was obtained upon application of $4.5 \mathrm{~kg} \mathrm{~m}^{-2}$ of $M$. aegyptia beds and goat manure. The consortium presented an area ratio equivalent to 1.0 , with an average value of 1.83 in the amount of $4.5 \mathrm{~kg} \mathrm{~m}^{-2}$ of $M$. aegyptia flower bed plus goat manure. The consortium contributed to better use of available resources without compromising the commercial quality of the vegetables.

\section{Acknowledgements}


Special thank the Jitirana (Merremia aegyptia L.) Research Group committed to the study of spontaneous species of the Caatinga Biome as fertilizer source and the Department of Agronomic and Forestry Sciences the Federal Rural SemiArid University (UFERSA), for the support in the conduction of the project.

\section{References}

Almeida AES, Bezerra Neto F, Costa LR, Silva ML, Lima JSS, Júnior APB (2015) Eficiência agronômica do consórcio alface-rúcula fertilizado com flor-de-seda. Revista Caatinga, Mossoró 28:79-85.

Altieri M (2004) Agroecologia: a dinâmica produtiva da agricultura sustentável. Porto Alegre: Editora da UFRGS.

Caetano LCS, Ferreira JM, Araújo M (1999) Produtividade da alface e cenoura em sistema de consorciação. Horticultura Brasileira. 17:143-146.

Carmo Filho F, Oliveira OF (1995) Mossoró: um município do semi-árido nordestino, caracterização climática e aspecto florístico. Mossoró: ESAM. 62 p. (Coleção Mossoroense, Série B).

Costa CC (2006) Consórcio de alface e rúcula: aspectos produtivos e econômicos. $83 \mathrm{p}$. Tese (Doutorado em produção vegetal) - Faculdade de Ciências Agrárias e Veterinárias, Universidade Estadual Paulista - Jaboticabal.

Charnes A, Cooper WW, Rhodes E (1978) Measuring the efficiency of decision-making units. European Journal of Operational Research. 2:429-444.

Empresa Brasileira de Pesquisa Agropecuária - Embrapa (2006) Sistema brasileiro de classificação de solos. 2.ed. Rio de Janeiro: Embrapa, p.306.

Filgueira FAR (2012) Novo manual de olericultura: Agrotecnologia moderna na produção e comercialização de hortaliças. Viçosa: UFV, 2012. 421p.

Fukushi YKM (2012) Manejo de plantas espontâneas em sistemas consorciados de hortaliças. Brasília: Faculdade de Agronomia e Medicina Veterinária, Universidade de Brasília. 27 p (Monografia).

Gliessman SR (2001) Agroecologia: Processos ecológicos em agricultura sustentável. 2.ed., Porto Alegre: UFRGS, 658p.

Grangeiro LC, Negreiros MZ, Souza BS, Azevedo PE, Oliveira SL, Medeiros MA (2007) Acúmulo e exportação de nutrientes em beterraba. Ciência e Agrotecnologia 31:267273.

Jandel S (1991). Table curve: curve fitting software. Corte Madera, CA: Jandel Scientific. 280p.

Kottek M, Grieser J, Rudolf B, Rubel F (2006) Mapa mundial da classificação climática de Köppen-Geiger atualizada. Meteorologische Zeitschrift. 15: 259-263.

Kronka SN, Banzato DA. Estat: (1995) Sistema para análise estatística versão 2. 3. ed. Jaboticabal: Funep, 243 p.

Linhares PCF, Lima GKL, Madalena JAS, Maracajá PB, Fernandes PLO (2008). Adição de jitirana ao solo no desempenho de rúcula cv. Folha Larga. Revista Caatinga. 21:89-94.

Novaes RF (2007) Fertilidade do solo. In: MEURER, E.J. Fatores que influenciam $O$ crescimento $e$ o desenvolvimento das plantas. Viçosa: SBCS, p. 65-90.

Oliveira KJB, Lima JSS, Soares APS, Bezerra Neto F, Linhares PCA (2015). Produção agroeconômica da rúcula fertilizada com diferentes quantidades de Calotropis procera. TERCEIRO INCLUÍDO ISSN 2237-079X NUPEAT-IESA-UFG 5: 373-384.

Oliveira KJB (2014) Desempenho agroeconômico do bicultivo de rúcula consorciada com beterraba em função de quantidades de flor-de-seda e arranjos espaciais. Dissertação (Mestrado em Fitotecnia) - Universidade Federal Rural do Semi-Árido (UFERSA), Mossoró-RN, $103 f$.

Oliveira EQ, Souza RJ, Cruz MCM, Marques VB, França AC (2010) Produtividade de alface e rúcula, em sistema consorciado, sob adubação orgânica e mineral. Horticultura Brasileira. 28:36-40.

Ramalho WB (2015) Consórcio de coentro com beterraba, adubos com quantidades de jitirana, combinada com esterco bovino no desempenho agroeconômico. $75 f$. Dissertação (Mestrado em sistemas agroindustriais) Universidade Federal de Campina Grande (UFCG), Pombal.

Rêgo LGS, Martins CM, Silva EF, Silva JJA, Lima RNS (2016) Pedogenesis and soil classification of na experimental farm in Mossoró, state of Rio Grande do Norte, Brasil. Revista Caatinga. 29:1036-1042.

Silva IN (2013) Bicultivo de alface consorciada com beterraba sob diferentes quantidades de Jitirana incorporadas ao solo e arranjos espaciais. 73p. Dissertação (Mestrado em Fitotecnia) - Universidade Federal Rural do Semi-Árido.

Silva ML (2012) Viabilidade agronômica de hortaliças fertilizadas com flor-de-seda (Calotropis procera (Ait.) R. Br.). 83f. Tese (Doutorado em Agronomia: Fitotecnia) Universidade Federal Rural do Semi-Árido (UFERSA), Mossoró-RN.

Souza JL, Resende P (2006) Manual de Horticultura Orgânica. 2o Ed. Viçosa- MG: Aprenda Fácil. 843 p.

Taiz L, Zeiger E (2017) Fisiologia e Desenvolvimento Vegetal. 6.ed. Porto Alegre: Artmed, 888p. 